\title{
Free Speech, the Private Employee, and State Constitutions
}

All too frequently, individual employees who express personal political views obnoxious to their employers are discharged from their jobs or subjected to other forms of retaliation. ${ }^{1}$ Federal constitutional guarantees protect public employees, but do not extend to workers in the private sector. Moreover, the National Labor Relations Act and analogous state legislation protect only unionized private employees, and only when those employees engage in "concerted activities." Although common-law remedies for wrongful discharge have been adopted in some states, these very limited remedies do not explicitly protect free expression. ${ }^{2}$

This Note argues that free expression by nonunion employees in the private sector is increasingly threatened and requires greater protection. While acknowledging competing constitutional values and policy objections, it concludes that protection of employee speech in proper circumstances is essential to our system of free expression and that, in the absence of federal judicial willingness to intervene in the employment relationship, the linguistically broad free speech provisions of state constitutions provide a means for such protection. After analyzing competing concerns, the Note suggests two circumstances in which protection of employee speech is inappropriate and describes factors state courts should

1. Several authors have argued that increased employee protection against arbitrary employer action in general is overdue. Sec, e.g., Blades, Employment at Will vs. Individual Freedom: On Limiting the Abusive Exercise of Employer Power, 67 CoLUM. L. REV. 1404 (1967); Blumberg, Corporate Responsibility and the Employee's Duty of Loyalty and Obedience: A Preliminary Inquiry, 24 OKLA. L. REV. 279 (1971). This Note contributes to that discussion by arguing that the values underlying the system of free expression require such protection. The Note differs from these earlier works by proposing state constitutional guarantees, rather than common law or statutory reforms, as a basis for protection of employee speech. Earlier authors have debated whether employee protection is possible through federal constitutional interpretation. Compare Berle, Constitutional Limitations on Corporate Activity-Protection of Personal Rights from Invasion Through Economic Power, 100 U. PA. L. REV. 933 (1952) (predicting trend toward such protection through Fifth and Fourteenth Amendments) with Wellington, The Constitution, the Labor Union and "Governmental Action", 70 YALE L.J. 345 (1961) (arguing against it). None has analyzed the potential of state constitutions for guaranteeing employee free expression.

2. The term "expressive activity" as used in this Note refers to nonviolent, noncoercive, direct communication between individuals, including but not limited to mass audiences. See Baker, Scope of the First Amendment Freedom of Speech, 25 U.C.L.A. L. REV. 964, 990-96 (1978); see generally T. EMERSON, THE SYSTEM OF FṚEEDOM OF EXPRESSION (1970). 
weigh in deciding the remainder of cases involving the speech of private employees.

\section{Freedom of Expression and the Employment Relationship}

Although some employees are currently protected against employer retaliation, these protections are inadequate. Political speech by an employee, the paradigmatic case, remains unprotected from employer reprisal.

\section{A. Existing Guarantees}

Many employees already enjoy protection against employer abridgment of speech. Since 1968, the First Amendment ${ }^{3}$ has been interpreted to protect the right of public employees to comment on matters of either public or private concern. ${ }^{4}$ This protection extends to both federal and state employees, ${ }^{5}$ as well as to those employed by entities sufficiently connected with government that their actions qualify as state action. ${ }^{6}$

State and federal labor laws provide additional protection. Section 7 of the National Labor Relations Act (NLRA) ${ }^{7}$ protects employee speech from abridgment by employers when employees are engaged in "concerted activities" for "mutual aid or protection." Although the "concerted activi-

3. U.S. Const. amend. I ("Congress shall make no law ... abridging the freedom of speech ....") The Supreme Court applied the First Amendment protection of free speech to the states in Gitlow v. New York, 268 U.S. 652, 666 (1925) ("liberty" protected by due process clause of Fourteenth Amendment includes freedom of expression).

4. Prior to 1968, public employees were not guaranteed freedom of expression. See McAuliffe v. Mayor of New Bedford, 155 Mass. 216, 220, 29 N.E. 517, 517 (1892) (Holmes, J.) (plaintiff has right to express himself but "no constitutional right to be a policeman"). Pickering v. Board of Educ., 391 U.S. 563, 568 (1968), held that public employees may not be required to relinquish First Amendment rights in order to enjoy public employment. The Court adopted a balancing test, weighing the employer's interest in efficiency against the employee's interest in free expression. Pickering has recently been applied to expressions of opinion in private encounters. See Givhan v. Western Line Consol. School Dist., 439 U.S. 410, 413 (1979) (unanimous) (expression of public employee's views in private encounters with employer not beyond constitutional protection). Pickering and Givhan both involved state employees. Similar protection has been found for federal employees, see Singer v. United States Civil Serv. Comm'n, 429 U.S. 1034 (1977) (summarily vacating lower court affirmance, reported at 530 F.2d 247 (9th Cir. 1976), of dismissal of EEOC secretary for off-duty advocacy of homosexuality), and for municipal employees, see Bickel v. Burkhart, 462 F. Supp. 682, 684 (N.D. Tex. 1978) (finding First Amendment protection for local fireman).

5. See supra note 4.

6. Two tests for state action have been used by courts: the public function test and the significant state involvement test. The latter has been narrowed by requiring a "close nexus" between governmental and challenged activity. For a summary of the doctrines, see Note, Creditors' Remedies as State Action, 89 YALE L.J. 538, 540-45 (1980).

7. 29 U.S.C. $\S \S 151-168$ (1976).

8. "Employees shall have the right to self-organization, to form, join, or assist labor organizations, to bargain collectively through representatives of their own choosing and to engage in other concerted activities for the purpose of collective bargaining or other mutual aid or protection . . ." 29 U.S.C. $\S 157$ (1976) [hereinafter referred to as § 7]. While Congress may have initially passed the $\S 7$ protections to promote collective bargaining rather than to extend free speech guarantees to organized 
ties" limitation of section 7 was once defined to apply only to disputes between employees and their employer, recent case law interprets it to apply to any speech with sufficient relation to employee group interests.' These free speech rights are considered "fundamental,"10 and may not be bargained away by union representatives in contract negotiations. ${ }^{11}$ Twenty-three states have enacted similar provisions. ${ }^{12}$

Several states have also enacted legislation to protect the political activities of employees. Such laws prohibit employers from, for example, reduction of an employee's wages or dismissal in order to influence her vote, ${ }^{13}$ interference with an employee's "engaging in politics or becoming a candidate," 14 or discrimination against an employee on the basis of her "political activities or affiliations." 15

private employees, judicial use of First Amendment doctrine to interpret $\S 7$ has produced the latter result. See Republic Aviation Corp. v. NLRB, 324 U.S. 793, 803 (1945) (affirming NLRB presumptions for protected speech); Lynd, Employee Speech in the Private and Public Workplace: Two Doctrines or One?, 1 INDUS. REL. L.J. 711, 713-20 (1977) (showing NLRB presumptions based upon First Amendment doctrine).

9. Eastex, Inc. v. NLRB, 437 U.S. 556, 564-65 (1978) (finding distribution of newsletter containing lobbying news on pro-labor legislation protected under $\$ 7$ ). Eastex indicated that, at some point, the relationship between the employees' speech and work would probably become "so attenuated" that protection would not be appropriate, but the Court declined to define that point. Id. at 568. Cr. Ford Motor Co., 221 NLRB 663, 666 (1975), enforced, 546 F.2d 418 (3d Cir. 1976) (cited in Eastex) (holding distribution on employer's premises of a "purely political tract" unprotected even though election of any political candiate ultimately might affect employment conditions).

10. NLRB v. Jones \& Laughlin Steel Corp., 301 U.S. 1, 33 (1937).

11. NLRB v. Magnavox Co., 415 U.S. 322, 325 (1974). The NLRB has applied this holding as if it "prohibits the waiver of the right to distribute literature connected with any activity protected by section 7." Lynd, supra note 8 , at 724-25. These rights may therefore be characterized as quasiconstitutional. Id. at 726 .

12. Each of the state statutes protects other "concerted activities . . . for mutual aid and protection" in language identical to the federal statute. See COLO. REV. STAT. § 8-3-106 (1973); CoNN. GEN. STAT. § 31-104 (1981); HAWAII REV. STAT. § 377-4 (1976); IDAHO CODE § 48-701 (1977) (statement of public policy only, without enforcement provision); IND. CODE $\S 22-6-1-2$ (1974) (statement of public policy only, without enforcement provision); KAN. STAT. ANN. § 44-803 (1973); LA. REV. STAT. ANN. $§ 23: 822$ (West 1964) (statement of public policy only, without enforcement provision); MD. WORK, LAB. \& EMPL. CODE ANN. art. 100, §63 (1964); MASS. GEN. LAWS ANN. ch. 150A, $\S 3$ (West 1976); MICH. COMP. LAWS $\S 423.8$ (1978); MINN. STAT. $\$ 179.10$ (1966); NEV. REV. STAT. $\$ 614.090$ (1979) (statement of public policy only, without enforcement provision); N.Y. LAB. LAW $\S 703$ (McKinney 1977); N.D. CENT. CODE § 34-12-02 (1980); OR. REV. STAT. § 663.110 (1979); PA. STAT. ANN. tit. 43, § 211.5 (Purdon 1964); R.I. GEN. LAWS $\S ~ 28-7-12$ (1979); S.D. CODIFIED LAWS ANN. § 60-9A-2 (1978); UTAH CODE ANN. § 34-20-7 (1974); VT. STAT. ANN. tit. 21 § 1503 (1979); W. VA. CODE $§ 21-1 A-3$ (1981); WIS. STAT. ANN. § 111.04 (West 1974); WYO. STAT. ANN. \& 27-7-101 (1977). Some states, such as Connecticut, have adopted state penalties for violations of the NLRA. See Nelson, State Labor Legislation Enacted in 1980, MO. LABOR REV., Jan. 1981, at 21,22 (listing states).

13. MASS. GEN. LAWS ANN. ch. 56, § 33, (1978).

14. NEV. REV. STAT. $\$ 613.040$ (1979). See COLO. REV. STAT. $\$ 8-2-108$ (1973).

15. CAL. LABOR CODE $\S \S 1101-1105$ (West 1971). For a detailed analysis of California's statutory protections, see Note, California's Controls on Employer Abuse of Employee Political Rights, 22 STAN. L. REV. 1015 (1970). Although some statutes provide civil remedies for the employee, see, e.g., CAL. LABOR CODE $\S 1105$ (West 1971) (private recovery not precluded); NEV. REV. STAT. $§ 613.070$ (1979) (private recovery allowed), others provide only criminal penalties, see, e.g., MO. REV. STAT. $\S 115.637(7)$ (Vernon 1966). For additional state statutes protecting political activities, sec LA. REV. STAT. ANN. § 23:961-62 (West 1964); MINN. STAT. ANN. § 210A.14 (West Supp. 1981); WIS. STAT. 
The common law also provides some protection. Nine states, following New Hampshire's lead in $1974,{ }^{16}$ now recognize a cause of action against an employer for the tort of wrongful discharge. ${ }^{17}$ Wrongful discharge has been interpreted broadly as dismissal contrary to public policy and has included, in some cases, dismissal resulting from an employee's expressive activity. ${ }^{18}$

Current legal safeguards for freedom of expression, however, usually do not protect the speech of nonunion workers employed in the private sector. ${ }^{19}$ Under the most recent state-action tests, almost no private employer is bound by the constraints of the First and Fourteenth Amendments. ${ }^{20}$

\section{ANN. § 12.19 (West 1974).}

16. See Monge v. Beebe Rubber Co., 114 N.H. 130, 316 A.2d 549 (1974) (allowing damages for employee discharged after refusing to engage in sexual relations with employer). Monge is regarded as the seminal case, but there are earlier cases vindicating employee expressive rights. See Peterman v. Teamsters Local 396, 174 Cal. App. 2d 184, 344 P.2d 25 (1959) (allowing damages for employee discharged by union for failure to testify falsely before legislative committee).

17. Those states are California, Illinois, Indiana, Massachusetts, Michigan, New Hampshire, Pennsylvania, Oregon, and West Virginia. See Note, Protecting the At Will Employee Against Wrongful Discharge: The Duty to Terminate Only in Good Faith, 93 HARV. L. REV. 1816, 1817 nn.6-7, 1821 n.30, 1822 n.38 (1980) (listing cases). Connecticut also has adopted the doctrine. See Sheets v. Teddy's Frosted Foods, 179 Conn. 471, 427 A.2d 385 (1980). Three approaches to the doctrine of wrongful discharge exist so far. Some states imply an employer's contractual duty to terminate only in good faith, others impose tort obligations for abusive or retaliatory discharge, and still others merely recognize a public policy exception to the employment at will doctrine. Note, supra, at 1821-24.

18. See Harless v. First National Bank, 246 S.E.2d 270 (W. Va. 1978) (allowing recovery for dismissal in retaliation for reporting bank illegalities to bank director). Most cases, however, do not consider the needs of the system of free expression. See cases cited infra nn. 26-37.

19. The non-agricultural work force in 1976 numbered close to 80 million. Over 15 million were employed by federal, state or local governments, and hence protected by the First Amendment. Close to 21 million were unionized. Of those unionized, $95 \%$ were protected by grievance procedures, and $80 \%$ had won "good cause" clauses in their collective bargaining contracts. Thus, approximately 60 $65 \%$ of the non-agricultural work force, or about $48-52$ million workers, were unprotected and terminable at will. Peck, Unjust Discharges from Employment: $A$ Necessary Change in the Law, 40 OHIO ST. L.J. 1, 8-9 (1979).

This Note analyzes only protection for nonunion employees. For a discussion of the difficulties of protecting free expression through arbitration, see Palmer, Free Speech and Arbitration: Implications for the Future, 27 LAB. L.J. (1976), reprinted in INDIVIDUAL RIGHTS IN THE CORPORATION 156, 170 (A. Westin \& S. Salisbury eds. 1980) (suggesting that Supreme Court probably would deny to arbitrators the power finally to decide cases involving constitutional rights). But see J. GETMAN, LABOR RELATIONS: LAW, PRACTICE AND POLICY $367-70$ (1978) (arbitrators tend not to consider constitutional issues). Although $\S 7$ of the NLRA theoretically would protect individual speakers, courts usually have interpreted "concerted activities" to require at least contemplation of group action. See, e.g., Tri-State Truck Service v. NLRB, 616 F.2d 65, 71 (3d Cir. 1980); NLRB v. Dawson Cabinet Co., 566 F.2d 1079, 1082 (8th Cir. 1977); NLRB v. Buddies Supermarkets, 481 F.2d 714, 718 (5th Cir. 1973).

20. See Griffith v. Bell-Whitley Community Action Agency, 614 F.2d 1102, 1109-10 (6th Cir. 1980) (employee complaint failed to state cause of action because agency was not engaged in federal action at time of termination); Johnson v. Southwest Detroit Community Mental Health Serv., 462 F. Supp. 166, 167, 171 (E.D. Mich. 1978) (finding neither sufficient nexus nor symbiotic relationship to establish state action where non-profit agency receives $90 \%$ of its income from government, enjoys state tax benefits given to non-profit corporations, is subject to extensive regulation by H.E.W. and by corresponding state agency, and is subject to site visits by H.E.W.). But see Holodnak v. Avco Corp., 514 F.2d 285, 288-89 (2d Cir.) cert. denied, 423 U.S. 892 (1975) (finding sufficient government involvement to apply First Amendment where nearly all of company's physical plant was owned by 
Statutes also provide little protection. Protection of speech under section 7 of the NLRA and analogous state laws does not apply to individual employees or to employees not acting to secure a group benefit. ${ }^{21}$ Moreover, state "political activities" statutes apply only to electoral activities. ${ }^{22}$ Nor does the developing common-law cause of action for wrongful discharge comprehensively protect freedom of expression; ${ }^{23}$ thus far, it has been recognized by only nine states. ${ }^{24}$ All such nonconstitutional protections are, of course, subject to legislative nullification.

\section{B. Abridgment of Employee Expression by Private Employers}

Despite existing guarantees, private employers have successfully retaliated against employees for expressive activities. Employees have been dismissed, suspended, demoted, intimidated, and threatened with nonadvancement because of their expressive activities. ${ }^{25}$ Expressive activi-

government and $80 \%$ of work was for Department of Defense, which maintained large contingent of personnel on site to oversee operations).

21. See NLRB v. Dawson Cabinet Co., 566 F.2d 1079, 1082, 1084 (8th Cir. 1977) (worker acting alone found unprotected). Section 7 does not protect managerial employees, including foremen. See NLRB v. Bell Aerospace Co., 416 U.S. 267, 289 (1974). The speech must bear a fairly immediate relationship to employees' interests, see Eastex, Inc. v. NLRB, 437 U.S. 556, 565-568, n.18 (1978), and must be "inextricably linked with conduct" in order to qualify as "concerted activity," Lynd, supra note 8 , at 712 n.3.

22. Most of the statutes appear in code chapters dealing with electoral activities. See, e.g., MASS. GEN. LAWS. ANN. ch. 56, § 33 (1978); MO. REV. STAT. ANN. \& 115.637 (7) (Vernon 1966). Further, at least one state has excluded Communists from such statutory protection. See Black v. Cutter Laboratories, 43 Cal. 2d 788, 800-04, 278 P.2d 905 (1955), cert. dismissed, 351 U.S. 292 (1956) (finding Communist beliefs of employee to be defense against claim of wrongful discharge), cf. Lockheed Aircraft Corp. v. Superior Court, 28 Cal. 2d 481, 171 P.2d 21 (1946) (en banc) (statute does not prohibit employer from requiring a loyalty test). Most states, including Massachusetts, Colorado, Missouri and Louisiana, have not yet interpreted these statutes, although they were enacted for the most part in the 1930's. For a criticism of California's statutory controls, among the most broadly worded, as too weak and ineffectual, see Note, supra note 15.

23. The most common standard, that the discharge be contrary to public policy, is exceedingly vague. None of the three standards, see supra note 17 , requires or even suggests inquiry into the effects on values underlying the protection of free speech. See Note, supra note 17, at 1821-24 (describing issues to be considered under standards).

24. See supra note 17 (listed states). At least four jurisdictions have refused to apply the doctrine. See Hinrichs v. Tranquilaire Hosp., 352 So. 2d 1130, 1131 (Ala. 1977) (per curiam) (rejecting doctrine because standard "against public policy" is too broad); Larson v. Motor Supply Co., 117 Ariz. 507, 573 P.2d 907 (Ariz. Ct. App. 1977) (holding that employer can fire anyone); Sargent v. Illinois Inst. of Technology, 78 Ill. App. 3d 117, 121-22, 397 N.E.2d 443, 445-46 (1979) (affirming rule of termination at will despite predischarge hearing requirement of employee's manual); Scroghan $v$. Kraftco Corp., 551 S.W.2d 811, 812 (Ct. App. Ky. 1977) (finding termination to be private rather than public concern and deferring to legislature, which had not acted).

25. See, e.g., Griffith v. Bell-Whitley Community Action Agency, 614 F.2d 1102 (6th Cir. 1980) (laid off and offered lower status position); Harberson v. Monsanto Textiles Co., 13 Empl. Prac. Dec. (CCH) I 11,586, at 7128 (D.S.C. 1976) (dismissed); Francis v. American Tel. \& Tel. Co., 55 F.R.D. 202 (D.D.C. 1972) (suspended, later dismissed; found protected under Title VII); Pierce v. Ortho Pharmaceutical Corp., 166 N.J. Super. 335, 337-338, 340 (1979), rev'd, 84 N.J. 58, 417 A.2d 505 (1980) (constructive discharge found when resignation based on threatened nonadvancement); In re Chalk, 441 Pa. 376, 379, n.1, 272 A.2d 457 (1971) (warned not to speak out); EEOC Decision No. 71-2040, May 12, 1971, summarized in Empl. Prac. Rptr. If 622.5011 (duties reassigned). Most 
ties leading to such reprisals have included advocating Communism, ${ }^{26}$ advocating homosexuality, ${ }^{27}$ filing grievances charging wrongdoing by superiors, ${ }^{28}$ writing letters critical of management to newspapers or government agencies, ${ }^{29}$ publishing an "underground" company newsletter, ${ }^{30}$ voicing misgivings about product safety, ${ }^{31}$ announcing intentions of attending law school at night, ${ }^{32}$ writing a novel, ${ }^{33}$ counseling a fellow employee of her legal rights against the employer, ${ }^{34}$ criticizing a superior, ${ }^{35}$ implying a racial bias on the part of the employer, ${ }^{36}$ and advocating women's rights. ${ }^{37}$ In almost every case, the employer prevailed against a court challenge.

reported cases involve discharge rather than other forms of retaliation. For examples of cases involving employees who wished to differ publicly with their employers, see WHISTLE BLOWING: THE REPORT OF THE CONFERENCE ON PROFESSIONAL RESPONSIBILTY 140-46 (R. Nader, P. Petkas \& K. Blackwell eds. 1972) (suspension); Id. at 152-54 (demotion).

26. See, e.g., Black v. Cutter Laboratories, 43 Cal. 2d 788, 800, 804, 278 P.2d 905 (1955), cert. dismissed, 351 U..S. 292 (1956); Lockheed Aircraft Corp. v. Superior Court, 28 Cal. 2d 481, 485, 171 P.2d 21 (1946) (en banc) (employer engaged in producing vital war materials); Allure Shoe Corp. 138 N.L.R.B. 395, 406 (1962) ("pro-Castro" and "communistic" employees). Unless indicated, the employer prevailed in all cases cited infra at nn.26-37.

27. See, e.g., DeSantis v. Pacific Tel. \& Tel. Co., 608 F.2d 327 (9th Cir. 1979); Smith v. Liberty Mut. Ins. Co., 569 F.2d 325 (5th Cir. 1978); Holloway v. Arthur Andersen \& Co., 566 F.2d 659 (9th Cir. 1977) (transsexual). But see Gay Law Students Ass'n v. Pacific Tel. \& Tel. Co., 24 Cal. 3d 458, 595 P.2d 592, 156 Cal. Rptr. 14 (1979) (complaint stated cause of action under state constitution's equal protection clause, state utility code, and state labor code protecting political activity).

28. Sec, e.g., Johnson v. Southwest Detroit Community Mental Health Serv., 462 F. Supp. 166 (E.D. Mich. 1978) (approached FBI agents to determine if actions of agency superiors violated federal law); Sheets v. Teddy's Frosted Foods, 179 Conn. 471, 427 A.2d 385 (1980) (complained to superior about violations of state food and drug act; court reversed grant of employer's motion to dismiss); Martin v. Platt, 386 N.E.2d 1026 (Ct. App. Ind. 1979) (reported that immediate superior was receiving kickbacks); Sargent v. Illinois Inst. of Technology, 78 Ill. App. 3d 117, 397 N.E.2d 443 (1979) (campus policeman filed grievance alleging "theft of services" by immediate superior who used employer's property for personal purposes); Harless v. First National Bank, 246 S.E.2d 270 (W. Va. 1978) (reported supervisor's procedural illegalities to bank director).

29. See, e.g., Holodnak v. Avco Corp., 514 F.2d 285 (2d Cir.), cert. denied, 423 U.S. 892 (1975) (letter to weekly newspaper criticizing grievance procedure of employer and union); Percival v. Gencral Motors Corp., 400 F. Supp. 1322 (E.D. Mo. 1975) (letter to corporate superior and to joint venture partner of employer correcting 15 perceived errors in employer's newspaper ads); Abrisz v. Pulley Freight Lines, 270 N.W.2d 454 (Iowa 1978) (letter to unemployment compensation board in support of co-worker's claim criticizing employer practices).

30. See Ingram, The Corporate Underground, 213 THE NATION 206, 207-09 (1971) (description of company reaction to such publications).

31. See Geary v. United States Steel Corp., 456 Pa. 171, 319 A.2d 174 (1974) (salesman criticized product safety).

32. See Scroghan v. Kraftco Corp., 551 S.W.2d 811, 812 (Ct. App. Ky. 1977).

33. See MeIntyre v. E.I. DuPont, No. 954,904 (165th Judicial District Court, Harris Co., Texas, 1974).

34. See Berg v. LaCrosse Cooler Co., 612 F.2d 1041 (7th Cir. 1980) (personnel department employee counseled co-worker on perceived legal right to pregnancy benefits; disagreed with superior; found protected under Title VII).

35. See Griffith v. Bell-Whitley Community Action Agency, 614 F.2d 1102 (6th Cir. 1980) (opposed election of executive director by board of directors); Heiskala v. Johnson Space Center Credit Union, 474 F. Supp. 448 (S.D. Tex. 1979) (criticized managerial decisions, operations and procedures); Lewis v. Ford Motor Co., 17 Empl. Prac. Dec. (CCH) I 8453, at 6350 (E.D. Mich. 1978) (termination for unprofessional outburst).

36. See H.L. Meyer Co. v. NLRB, 426 F.2d 1090, 1093 (8th Cir. 1970) (employee implied racial discrimination by employer against job applicant). 
While the above cases reflect a range of employer abridgment, the paradigmatic reprisal occurs when an employee is engaged in political expressive activity after working hours and off company property. For example, an employee fired for speech critical of an incumbent President of the United States, by an employer whose views differed, has no recourse from or protection against such a reprisal.

Employees ordinarily cannot vindicate their rights by leaving their jobs. To do so in the modern employment context, where more people than ever before work for others, ${ }^{38}$ often entails the loss of pensions ${ }^{39}$ and seniority. ${ }^{40}$ Further, technological advances have increased employers' ability to dis-

37. EEOC Decision No. 73-0463, Jan. 19, 1973, summarized at Empl. Prac. Rptr. I 566.11 (leader of women's rights committce who worked in personnel department and had access to confidential information discharged).

38. Geary v. United States Steel Corp., 456 Pa. 171, 176, 319 A.2d 174, 176 (1974) ("We have become a nation of employees.") (quoting F. TANNENBAUM, A PHILOSOPHY OF LABOR 9 (1951)). Further, more workers now work for very large corporations. The number of employces of the nation's 500 largest manufacturing companies has risen in the last 25 years nearly three times as fast as has the number of workers employed by the remainder of United States manufacturers. Sce Hayes, Twenty-Five Years of Change in the Fortune 500, FoRTUNE, May 5, 1980, at 88, 94 (chart). In 1980 , over 4.6 million workers, or nearly $28.7 \%$ of all "Fortune 500 " employees, were employed by the top 20 "Fortune 500" manufacturers. Id.

39. Pension plans now cover well over half of the private sector labor force. P. DRUKER, THE UNSEEN REVOLUTION: HOW PENSION FUND SOCIALISM CAME TO AMERICA 15 (1976). Employees must usually work for the same employer for several years in order to vest in the plan. See Glendon \& Lev, Changes in the Bonding of the Employment Relationship: An Essay on the New Property, 20 B.C. L. REV. 457, 476-77 (1979). The federal government, with the Employee Retirement Income Security Act (ERISA), has encouraged formation of pension plans. ERISA preempted state statutes requiring pension plans. See Int'] Bhd. of Teamsters v. Daniel, 439 U.S. 551, 569-570 (1979) (ERISA comprehensively governs use and terms of pension plans).

40. Seniority limits an employee's freedom to change jobs. Benefits such as regular increases in pay, vacations, promotions, protection against layoffs, and priority in recall improve as seniority increases. Glendon \& Lev, supra, note 39 at 478-79. See J. GETMAN, supra note 19, at 37, 181 (seniority has been described as "soul" of collective bargaining agreement for unionized employees). Employees who change employers must ordinarily begin to accumulate seniority all over again. Glendon and Lev point out that, while seniority is traditionally associated with collective bargaining, most "employers that have successfully resisted unionization often have done so by providing wages and benefits equal to or better than their unionized counterparts." Glendon \& Lev, supra note 39, at 478 . Thus, seniority has become a significant deterrent to changing jobs. See SUBCOMMITTEE ON FISCAL POLICY OF THE JOINT ECONOMIC COMMITTEE, 93RD CONGRESS, 1ST SESSION, THE LABOR MARKET IMPACTS OF THE PRIVATE RETIREMENT SYSTEM 67-71 (Comm. Print 1973) (number of annual quits per hundred employees usually lower in establishments with pension plans); Flowers \& Hughes, Why Employees Stay, HARV. BUS. REV., July-August 1973, at 49 (describing factors that promote job stability despite increased dissatisfaction); Koludrubetz, Two Decades of Employee-Benefit Plans, 1950-1970: A Review, Soc. SEcuRITY Bull., April 1972, at 10; Schiller \& Weiss, The Impact of Private Pensions on Firm Attachment, 61 REV. OF ECON. AND STATISTICS 369 (1979) (analyzing aspects of different plans).

Less tangible forces also tend to make job-changing difficult. Fear of, or inability to adapt to new situations, particularly as a worker gets older, contribute to a lack of worker mobility. See Rosen, Management Perception of Older Employees, MO. LAB. REV., May 1978, at 33 (older workers' fears of discrimination are not unfounded because employers accept age stereotypes and believe that hiring older workers will raise medical insurance premiums). See generally Hearings on Age Discrimination in Employment Before Subcommittee on Labor of the Senate Comm. on Labor and Public Welfare, 90th Cong., 1st Sess. (1967). The job-seeking experience can itself be emotionally trying as well, involving the potential for, if not the repeated incidence of, personal rejection. 
cover, monitor, and retrieve personal information about the beliefs and opinions of individual workers. ${ }^{41}$ Thus, employers now hold an unprecedented ability to coerce large numbers of employees' beliefs and opinions.

\section{Balancing Employee Speech with Competing Employer Interests}

The values underlying freedom of expression, together with the coercive power of many employers, creates a situation which requires protection of employee speech. Because such protection may restrict employer freedom, however, a proper balance must be struck.

\section{A. The Need for Free Expression in the Workplace}

Democratic societies demand freedom of expression because it is essential to participation in decision-making by all members of society, individual self-fulfillment, the advancement of knowledge and the discovery of truth, and maintenance of the proper balance between stability and change. ${ }^{42}$ Inseparable from the ideal of freedom of expression is the pro-

41. Employers frequently make use of investigative agencies and information-gathering techniques to acquire information concerning an employee's beliefs and activities. See, e.g., Francis v. American Tel. \& Tel. Co., Long Lines Dept., 55 F.R.D. 202 (D.D.C. 1972) (on the job surveillance ordered after employee filed discrimination charges against employer); EEOC Decision No. 70-683 (April 10, 1970), summarized at Empl. Prac. Rptr. I 564.47 (employer assigned plant guards to keep Spanishsurnamed American employee under surveillance following employee's claims of job discrimination); STAFF OF SUBCOMAITTEE ON CONSTITUTIONAL RIGHTS OF THE COMMITTEE ON THE JUDICIARY, U.S. Senate, PRIVACY, Polygraphs aND EMPloYment, 93rd Cong., 2d Sess., 3 (Comm. Print 1974) $(200,000$ to 300,000 private business polygraph tests administered each year); Wall, What the Competition Is Doing: Your Need to Know, HARV. BuS. REV., Nov.-Dec. 1974, at 22, 38 (39\% of businesses surveyed admitted undercover operations, $38 \%$ admitted electronic surveillance, and $24 \%$ admitted surreptitious locker checks, in efforts to stem employee leaks), see V. PAGKARD, THE NAKED SOCIETY 91-102 (1964) (discussing use of lie detectors and psychological evaluations); A. WESTIN, PRIVACY AND THE EMPLOYMENT RELATIONSHIP: A STUDY OF COMPUTER USE IN PERSONNEL ADMINISTRATION (forthcoming), excerpted in INDIVIDUAL RIGHTS IN THE CORPORATION, supra note 19, at 226, 229; Craver, The Inquisitorial Process in Private Employment, 63 CoRNELl L. REV. 1, 28-64 (1977) (discussing employer's right to use lie detectors, searches, and surreptitious surveillance). See generally F. DONNER, THE AGE OF SURVEILLANCE (1980). The increased availability of high-speed information retrieval systems further threatens employee autonomy.

42. T. EMERSON, supra note 2, at 6-7; T. EMERSON, TOWARD A GENERAL THEORY OF THE FIRST AMENDMENT 3-15 (1966). Some commentators and jurists have suggested that the value of selfexpression is paramount. See, e.g., First Nat'l Bank of Boston v. Bellotti, 435 U.S. 765, 804-05 (1978) (White, J., dissenting) (principal function of First Amendment "self-expression, self-realization and self-fulfillment"); Cohen v. California, 403 U.S. 15, 26 (1971) (emotive value of expression often more important in overall message than cognitive content); L. TRIBE, AMERICAN CONSTITU. TIONAL LAW 578 (1978) (Meiklejohnian thesis that justifies protection of political speech is merely intermediate step because one underlying purpose of state is to enhance personal growth and selfrealization); Baker, supra note 2, at 991 (self-fulfillment and participation are key values), $c$. Whitney v. California, 274 U.S. 357, 375 (1927) (Brandeis, J., concurring) ("Those who won our independence believed that the final end of the State was to make men free to develop their faculties; and that in its government the deliberative forces should prevail over the arbitrary. They valued liberty both as an end and as a means.")

Some commentators, however, believe that self-expression is not a value guaranteed by the First Amendment and is unnecessary to a democratic society. See, e.g., Bork, Neutral Principles and Some First Amendment Problems, 47 IND. L.J. 1, 26 (1971). This view is decidedly in the minority. See 
tection of minorities ${ }^{43}$ whose ideas may be unpopular and who, by definition, are unable to protect themselves politically. ${ }^{44}$ The advancement of these values is threatened by the coercive power of private employers, nany of whom are now comparable to governments in size and intrusive power. ${ }^{45}$ Even without the trend toward large-scale corporatism, ${ }^{46}$ modern

Emerson, First Amendment Doctrine and the Burger Court, 68 CAL. L. REV. 422, 428 (1980) (summarizing popular acceptance of underlying values). Those who deny the value of self-expression usually tend to limit free expression to speech concerning matters of public concern, such as politics. See Bork, supra at 20 (no basis exists for judicial intervention to protect any speech but that which is "explicitly political"). Limitations of free speech guarantees to political speech, however, are necessarily tautological. Such limitations require definition of "political" speech. Political values are shaped much, perhaps most, by events and contexts which are not electoral. To the extent that judges are part of the contextual milieu, they cannot objectively-legitimately-define political speech. Moreover, the paradigmatic case, see supra p. 528, involves speech which Bork would protect.

43. Employees are not a numerical minority in the United States, but proponants of unpopular ideas are by definition in the minority. Although the term "minority" in Madison's time signified political or regional minorities rather than racial, religious or ethnic minorities, see Cover, The Origins of Judicial Activism in the Protection of Minorities, 91 YALE L.J. (1982) (forthcoming), intellectual deviates who differ with their employers are comprehended by the term as Madison used it. Workers as a group, possessed of smaller material wealth than employers, are likely to differ from their employers as a group on some issues. See THE FEDERALIST. No. 10 (J. Madison) (need to protect against factions; most common, durable source of factions has been "the various and unequal distribution of property"); Cover, supra, at n.3 (Madison's discussion of factions makes the point that "[p]roperty not only is itself an interest over which groups struggle, but it is an 'influence' on the 'sentiments and views' of its holders.") This difference cannot but influence electoral politics as well as less organic values. See supra note 42 (political speech shaped by milieu).

The Madisonian model of minority rights has, however, been criticized by Robert Dahl, who exposed its untestable assumptions. See R. DAHL, A PREFACE TO DEMOCRATIC THEORY 4-33 (1956) ("tyranny," inadequately defined yet central to theory, can be imposed by both majority and minority). Attractive to the empiricist, Dahl's approach ultimately has limited normative usefulness; even pain cannot be proven bad. Neither pain nor tyranny, of course, can be objectively defined or described. A more useful, if only historically available definition of tyranny comes from Robert Cover. See Cover, supra ("Each constitutional generation organizes itself about paradigmatic events and texts. For my generation it is clear that the events are Brown v. Board of Education and the Civil Rights Movement. The text is footnote four (of Carolene Products).") Cf. Fiss, Forward: The Forms of Justice, 93 HARV. L. REV. 1, 8, 15, 17 (1979) (footnote four radically incomplete; no discernable connection exists between majoritarianism and the meaning of a constitutional value).

44. Cf. J. ELY, DEMOCRACY AND DISTRUST 100-101, 103 (1980) (where majoritarian institutions fail to protect minority rights, judicial intervention is justified). Ely relies on the Madisonian model. - See id., at 7-8, 80. Although he nowhere defines the term minority, he explicitly includes dissenting or different individuals in his conception of the term, see id. at 178. See also id. at 76 (despite influence of footnote four, it has not been adequately elaborated).

45. The notion of a large corporation as a government becomes less remote when one examines the numbers of employees involved. The thirteen largest U.S. corporations in 1981 employed over $5,867,700$ workers. FORBES, May 11, 1981, at p. 299 (chart). The 1800 census of the United States counted only 5,308,483 people. 1 U.S. BUREAU OF THE CENSUS, HISTORICAL STATISTICS OF THE UNITED STATES 8 (1975) (table: Series A 1-5). The resemblance has been noted extensively by commentators. See, e.g., A. Miller, THE MODERN CORPORATE STATE (1975) (large corporations are private governments; constitution should reach them); Blumberg, supra note 1, at 299 (reasons for viewing large corporations as political institutions).

46. Political scientists have suggested that the United States and the nations of Western Europe are now in large part "corporatist" societies, in which government's objectives are carried out by private institutions. See R. HARRISON, PlURAlisM AND CORPORATISM (1980), cf. R. HeIl,BRONER, BUSINESS CIVILIZATION IN DEGLINE 34, 73 (1976) (next phase of capitalism must be increasingly planned system; drift of business society will be toward business-government state; hierarchies, bureaucracies and trend toward concentrate economic power likely to continue in post-industrial society).

Pluralism, which protests governmental intervention in private associations, has long been under 
employers can significantly impede the goals promoted by free expression. It might be argued that this impediment is minimal because the employee need only reserve expressive activity for nonworking hours or resign and find a more sympathetic employer. Employers, however, often successfully impose restrictions on employee activities even beyond working hours. ${ }^{47}$ Moreover, geographic restraints and specialized skills limit the ability of an employee to find comparable work elsewhere, particularly if sympathetic employers are rare. ${ }^{48}$

attack as a model for democratic theory. See P. BACHRACH, THE THEORY OF DEMOcRATIC ELITISM 83-92 (1967). Although pluralism may occasionally still function to protect non-majoritarian interests, see J. ELY, supra note 44, at 135 (relying on that assumption), its strength to protest governmental interference in non-governmental institutions is seriously weakened. A corporatist model, conversely, requires such interference to protect individual rights. Japan, the paradigmatic corporatist state, and Japanese industry are increasingly an enviable model for American business managers. See $W$. OUCHI, THEORY Z 74-79 (1981) (Japanese model of company resists deviance in all forms; is greatly sexist and rascist; model applied in America less intolerant of heterogeneity but tendency is still toward sameness). Moreover, some leaders of large businesses have openly endorsed the nation-corporation as an improvement over, and an alternative to, the nation-state. See R. BARNET \& R. MULLER, GLOBAL REACH 56 (1974) (remarks of A.W. Clausen, president of Bank of America).

The increased potential for employer coercion of employees has not gone unnoticed. See Bazelon, Civil Liberties-Protecting Old Values in the New Century, 51 N.Y.U. L. REv. 505, 512 (1976) ("With the advent of huge corporations, powerful unions and sophisticated technology, government no longer holds a monopoly on the power to invade liberty on a massive scale."); Wellington, supra note 1 , at 348 ("Unions and corporations have an importance in our lives which the founding fathers would have thought possible only of government itself.").

47. Sec, e.g., Aebisher v. Ryan, 622 F.2d 651, 655 (2d Cir. 1980) (recognizing chilling effect of public employer's coercive force on employee's speech); In re Chalk, $441 \mathrm{~Pa}$. 376, 379 n.1, 272 A.2d 457,458 , n.1 (1971) (housing authority warns employees, who were to appear as private individuals at meeting of tenants to urge lawful tenant action, that they must not "embarrass" the authority; court finds activity protected); EEOC Decision No. 73-0463, Jan. 19, 1973, summarized at Empl. Prac. Rptr. I 566.11 (personnel department employee successfully fired for work as leader of women's rights committee because of access to confidential personnel information); EEOC Decision No. 711850, April 21, 1971, summarized at Empl. Prac. Rptr. I 566.10 (labor union successfully discharges organizer for participation in demonstrations against what she believed to be racially discriminatory employment practices). The chilling effect of a threat of discharge has been recognized in the public employee context. See Pickering v. Board of Educ., 391 U.S. 563, 574 (1968) ("potent means of inhibiting speech"); Keyishian v. Board of Regents, 385 U.S. 589, 601 (1967) (chilling effect of "intricate administrative machinery").

48. The ability of employers to band together to exclude from work the adherents of certain ideologies has been amply demonstrated. See 1 REPORT ON BLACKLISTING 126, 130 (J. Cogley ed. 1956) (employer use of private loyalty boards to determine non-Communism of job applicants); 2 id. 15-19 (same); cf. N.D. CONST., art. XII \& 17 (prohibiting blacklisting). The assumption that citizens merely need reserve expressive activity for some other place was rejected by the Supreme Court when it struck down restrictions on expression imposed by municipalities, Schneider v. State, 308 U.S. 147, 163 (1939), and by owners of company towns, Marsh v. Alabama, 326 U.S. 501, 504-10, 504 n.1 (1946). Thus, the existence of an alternative means of communication cannot justify government foreclosure of a particular chosen means. "[O]ne is not to have the exercise of his liberty of expression in appropriate places abridged on the plea that it may be exercised in some other place." Schncider v. State, 308 U.S. 147, 162-165, 163 (1939). Municipal residents were not prevented from travelling to other towns to express themselves, yet the Court recognized that municipalities may not restrict free speech. This holding is consistent with the theory that because "cxit" from a town is sufficiently difficult, voice must be allowed within it.

Although these cases traditionally are cited as support for the doctrine of overbreadth, they rely on an assumption central to liberal democracy, i.e., illegitimate authority-authority tolerated despite its departure from liberal democratic tenets-is to be narrowly tolerated only to the extent that it is 
Freedom of expression operates as a system of underlying values, legal rules, and enforcing institutions. ${ }^{49}$ The ability of the employer to abridge deeply the expressive rights of large numbers of employees, heightened by the increased economic and social dependence of the employee on her job ${ }^{50}$ and by the typical imbalance in the employer-employee bargaining positions, ${ }^{51}$ seriously weakens this system. ${ }^{52}$ On this basis, ${ }^{53}$ governmental protection of employee speech in the private sector is both justified and essential. $^{54}$

justified by a desireable goal unachieveable within those tenets. See Hague v. C.I.O., 307 U.S. 496, 514,516 (1939) (opinion of Roberts, J.) (crucial issue whether officer or representative of state, clothed with authority of state, misuses his power); Lovell v. Griffin, 303 U.S. 444, 451 (1938) (unanimous) (ordinance invalid on face because not restricted in its application with respect to time and place); Marsh v. Alabama, 326 U.S. 501, 504-05, $504 \mathrm{n}$. 1 (following Lovell and Hague line of cases to find First Amendment prohibits abridgment of speech by owners of a company town).

49. See T. EMERSON, supra note 2, at 4 (overall unity of purpose and operation).

50. See supra notes $38-40$.

51. See supra notes $45-48$.

52. To fail to extend free speech protections to certain portions of the private sector is seriously to undermine those protections. "A system of freedom of expression that allowed private bureaucracies to throttle all internal discussion of their affairs would be seriously deficient." T. EMERSON, supra note 2 , at 677. See also id. at 564, 632. "Participation in public controversy involving the employer through the exercise of free speech presents the most appealing case for extension of employee rights." Blumberg, supra note 1, at 311. See also Wellington, infra note 104.

53. The importance of extending majoritarian democratic ideals to the often self-contained society of the workplace is implicit in the policy goals of the NLRA. Summers, Industrial Democracy: America's Unfulfilled Promise, 28 CLEV. ST. L. REV. 29, 33-34 (1979) (expectation and promise of Wagner Act was system of industrial democracy); 29 U.S.C. \$ 151 (1976) (policy goals). The recent Congressional treatment of Employee Stock Ownership Plans, although recognized as a "technique of corporate finance," I.R.S. Rev. Ruling 79-122, 1979-1, C.B. 204, 206, primarily reflects concern for industrial democracy. See Granados, Employee Stock Ownership Plans: An Analysis of Current Reform Proposals, 14 U. MICH. J. L. REF. 15, 16-18, 20 (1980) (describing other examples of preferential treatment). Just as in democracy at large, democracy in the workplace depends upon freedom of expression, even when that expression is not directly linked to the election of representatives.

[V]oluntary associations in our society tend to become, for all practical purposes, private governments. They grow into large, impersonal, bureaucratic machines, possessing an identity and life of their own. When this happens, the single member has no power by himself, and can exercise his influence only in common with others through the elaborate organizational machinery. In this situation the members of a voluntary association have the same need for freedom of expression as they do vis-a-vis the formal government. The function of a system of freedom of expression within such a private center of power is much the same as it is in the broader society.

T. EMERSON, supra note 2 at 676, cf. Thornhill v. Alabama, 310 U.S. 88, 103 (1940) ("Free discussion concerning the conditions in industry and the causes of labor disputes appears to us indispensable to the effective and intelligent use of the processes of popular government to shape the destiny of modern industrial society."); Holodnak v. Avco Corp., 381 F. Supp. 191, 204 (D. Conn. 1974), afrd, 514 F.2d 285 (2d Cir.), cert. denied, 423 U.S. 892 (1975) (citing passage from Thornhill). Indeed, the level of citizen participation in democracy at large may be significantly affected by workers' opportunities to participate in democracy in the workplace. See C. PATEMAN, PARTICIPATION AND DEMO. CRATIC THEORY 107-111 (1970); Conover, The Case for Participatory Management, in ANTICIPATORY DEMOCRACY: PEOPLE IN THE POLITICS OF THE FUTURE 195 (C. Bezold ed. 1978).

54. The ability to "exit" legitimates hierarchical bureaucracy in a liberal democracy. By exiting, individuals can avoid unwanted authority merely by removing themselves from its sphere of influence. See L. HARTZ, The Liberal Tradition IN AMERICA 64-65 (1955) (founders of United States were escaping from oppressive environment). When exit from a sphere of influence is sufficiently difficult, other characteristics are required to legitimate the authority. Cf. R. NOZICK, ANARCHY, STATE AND 


\section{B. Objections to Protection of Employee Speech}

Governmental protection of employee speech may infringe upon employers' rights of property, freedom of expression, and privacy. ${ }^{55}$ Analysis both of constitutional doctrine defining these rights and of related policy considerations helps to shape the appropriate limits of employee speech protection.

\section{Employer's Property Rights}

The Fifth and Fourteenth Amendments prohibit government from taking private property for public use without just compensation. ${ }^{56}$ Three of the "sticks" in the "bundle" of an owner-employer's protected property

UTOPIA 297-309 (1974) (the only moral state is minimalist association of like-valued individuals; citizens should choose states which asymptotically approximate their values); supra note 48 . Freedom of speech and conscience is a necessary if not sufficient condition for such legitimation. Compare J. ELY, supra note 44, at $178-79$ (tradition of exit is not strong enough to be a constitutional right, but dissenter for whom attempts at persuasion are unavailing should have a constitutional right to travel to find a more compatible majority, because majority appropriately chooses values), with Hirschman, Exit, Voice \& Loyalty: Further Reffections and a Survey of Recent Contributions, 1 SOC. SCIENCE INFORMATION 7 (1974) reprinted in 58 MILLBANK MEMORIAL FUND Q./ HEALTH \& SOCIETY 430, 444 (1980)(where both freedom of speech and exit are curbed, repression must occur).

55. Because the employment relationship is essentially contractual, it might be argued that governmental protection of employee speech would also violate the contracts clause, U.S. CONST., art. I, $\S 10, \mathrm{cl} .1$ ("No State shall .. . pass any . . . Law impairing the Obligation of Contracts . . ..") Once thought to be eclipsed by the protections of the Fifth and Fourteenth Amendments, the clause has been recently revived. See Allied Structural Steel Co. v. Spannaus, 438 U.S. 234, 241, 251 (1978) (declaring contracts clause "not a dead letter" and invalidating Minnesota law requiring certain employers to provide pension coverage). The contracts clause, however, does not represent a significant barrier to free speech protection. A court encountering a contracts clause question first should consider whether the state has substantially impaired the contractual relationship. Id. at 244 . "The severity of the impairment measures the height of the hurdle the state legislation must clear." Id. at 245 . The state may impose conditions upon contractual relations, but these conditions must be reasonable in light of the severity of the impairment and of the public purpose justifying their adoption. Id. Moreover, the state must be responding to an important social problem, id. at 247 , in a way that protects a broad societal interest rather than the interest of a favored group, id. at 249 . The Court has viewed with disfavor laws which "operate in an area [not] subject to state regulation at the time the . . contractual obligations were originally undertaken ...." Id. at 250 .

While protection of employee speech would limit the employer's contractual freedom by denying her the right to terminate an employee for any reason, the limitation would not be substantial, for the grant of protection would eliminate only one among many reasons for termination. Furthermore, protection of expressive rights is of broad societal interest, and private abridgment is an important social problem for which governmental protection is reasonable and appropriate. Finally, state and federal labor and civil rights legislation and regulation already pervades the area of employee discharge.

56. U.S. CONST. amend. 5 ("No person shall . . . be deprived of life, liberty, or property, without due process of law; nor shall private property be taken for public use, without just compensation."); U.S. CONST. amend. XIV, $\S 1$ ("No State shall make or enforce any law which shall abridge the privileges or immunities of citizens of the United States; nor shall any State deprive any person of life, liberty, or property, without due process of law . ....") Though the Fourteenth Amendment was adopted in 1868, it was not until 1897 that the takings clause was applied to the states through the due process clause. See Chicago, B. \& Q. R.R. v. Chicago, 166 U.S. 226, 241 (1897). The prohibition against taking private property was the first of the federal prohibitions to apply to the states; in 1925, freedom of speech became the second. Brennan, State Constitutions and the Protection of Individual Rights, 90 HARV. L. REV. 489, 493 (1977). 
rights ${ }^{57}$ are implicated by governmental protection of employee speech: an interest in the determination of how property is used, an interest in the ability to exclude others from its use, and an interest in the current and potential value of the property. ${ }^{58}$ It might be argued that protection of employee speech would substantially impair these interests and thus constitute an unlawful taking.

Whether or not a taking has occurred depends on the aggregate effect of the governmental action. ${ }^{59}$ State abridgment of the right to exclude is not a taking when the value or use of property is not substantially impaired and when the owner may impose reasonable time, place and manner restrictions on her property. ${ }^{60}$ When an employee has obeyed all reasonable employer regulations, government may limit an employer's right totally to bar expressive activity without violating the Fifth Amendment. ${ }^{61}$ Speech occurring outside company property cannot, by definition, impair the use of the employer's property, though it might impair the value.

Even if employee speech, regardless of location, affects the value of property by damaging sales, stock prices or the employer's reputation, it still need not constitute a proscribed taking. Governmental action that results in declines in value of up to $75 \%$ have been found constitutional in some cases, ${ }^{62}$ and complaints of lost potential profits, in particular, have constituted weak takings claims. ${ }^{63}$ The aggregate effect of a substantial loss of value, together with a partial loss of the right of exclude, however,

57. Property rights protected by the takings clause of the Fifth Amendment include an entire "group of rights inhering in the citizen's [ownership]." Pruneyard Shopping Center v. Robins, 447 U.S. 74, 82 n.6 (1980) (quoting United States v. General Motors Corp., 323 U.S. 373, 377-78 (1945)).

58. Id. (ownership includes rights to "possess, use or dispose of" property); Kaiser Aetna v. United States, 444 U.S. 164, 179-180 (1979) (right to exclude).

59. Pruneyard Shopping Center v. Robins, 447 U.S. 74, 83 (1980) (finding no taking because petitioning at shopping center will not unreasonably impair value or use of property); Armstrong v. United States, 364 U.S. 40, 48 (1960) (not every destruction or injury to property is a taking in the constitutional sense); Andrus v. Allard, 444 U.S. 51, 65-66 (1979) (aggregate of impairments must be viewed in its entirety); Michelman, Property, Utility and Fairness: Comments on the Ethical Foundations of "Just Compensation" Law, 80 HARV. L. REV. 1165, 1230-33 (1967) (test asks whether governmental measure deprived claimant of "some distinctly perceived, sharply crystallized, investment-backed expectation").

60. Pruneyard Shopping Center v. Robins, 447 U.S. 74 (1980).

61. Id. at 82-85.

62. Andrus v. Allard, 444 U.S. 51, 66 (1979) (reduction in value of property not necessarily a "taking"); Goldblatt v. Hempstead, 369 U.S. 590, 594-95 (1962) (magnitude of diminution of value no longer centrally determinative, proper procedure is to balance it against public purpose being served); Euclid v. Ambler Realty Co., 272 U.S. 365, 384 (1926) (loss of 75\% of total value not a "taking"); Hadacheck v. Los Angeles, 239 U.S. 394 (1915) (denying recovery to plaintiff who alleged diminution of $87.5 \%$ ); L. TRIBE, supra note 42 , at 461 n.3 (1978) (even loss of $75 \%$ may not be a "taking").

63. Andrus v. Allard, 444 U.S. 51, 66 (1979) ("loss of future profits-unaccompanied by any physical property restriction-provides a slender reed upon which to rest a takings claim"); $c f$. Fuller \& Purdue, The Reliance Interest in Contract Damages (Pt. 1), 46 YALE L.J. 52, 56-57, 59 (1936) (anticipated gains viewed as less compelling than other property interests). 
could result in a taking. ${ }^{64}$ Thus, a government seeking to protect employee speech must consider any loss of property value to the employer resulting from the speech.

Two of the most important values underlying the takings clause are that property should not be taken by the government for any but public purposes, and that the costs of improving the public welfare should not be borne by a few to benefit the many. ${ }^{65}$ The protection of employee speech need not significantly endanger these values. Freedom of speech is clearly a public good. ${ }^{66}$ Though employers may be "few" among society at large, ${ }^{67}$ they will be able in most cases to pass along to consumers any additional costs. A test that considers the employer's loss of property rights and allows reasonable time, place and manner restrictions on employee speech can adequately protect employers from any unreasonable burden.

Also underlying the protection of the individual employer's property rights is society's concern for worker productivity. Restricting employer prerogatives, it is argued, will not only weaken productivity but contribute to a decline in the quality of goods and services as firms are forced to retain non-productive workers. This concern, however, does not mandate limits on the protection of employee speech beyond those imposed by the employer's constitutional property rights.

Prohibiting employer retaliation need not adversely affect productivity or product quality. Many instances of employer retaliation against employee speech involve situations posing no threat to productive efficiency ${ }^{68}$ Employee protection from such retaliation may actually improve productivity in the long run. ${ }^{69}$ Employees who are protected against arbitrary

64. See Pruneyard Shopping Center v. Robins, 447 U.S. 74, 84 (1980) (right to exclude may be essential to use or economic value).

65. See Armstrong v. United States, 364 U.S. 40, 49 (1960); L. TRIBE, supra note 42, at 463; Michelman, supra note 59, at 1218-24. The latter value invites examination of the size of the benefit and the concentration of the cost. Thus, the Supreme Court has adopted a balancing test for evaluating takings claims. A small cost, even if borne by only a few, would interfere minimally with this value.

66. See Pruneyard Shopping Center v. Robins, 447 U.S. 74, 85 (1980) (state's asserted interest in expansive free speech and petition rights meets due process test for real and substantial relation to objective sought).

67. Some employers may actually represent a large group of investors and thus more closely resemble "many" than "few."

68. Many dismissals result from challenges to the perceived authority of the employer rather than from challenges to productivity. See D. EWING, FREEDOM INSIDE THE ORGANIZATION: BRINGING CIVIL LIBERTIES TO THE WORKPLACE 94 (1977) (greatest management fear is perceived threat to hierarchy of power). For examples of cases where non-productivity reasons for dismissal were cited, see supra pp. 527-28. A rule that permits an employer to discharge an employee whose speech seriously interferes with productivity would avoid any significant economic damage to the employer. See Note, supra note 17 , at 1835.

69. See Note, supra note 17, at 1835 . Indeed, several corporations have begun to encourage free speech voluntarily. See D. EwING, supra note 68, at 95-96 (describing corporate endorsement of "gripe sessions," critical team reviews, and anonymous telephone and card systems). 
dismissal - that is, dismissal unrelated to productive efficiency--have reduced rates of absenteeism, turnover and sabotage. ${ }^{70}$ Germany, England, Sweden and France, apparently without damage to their economies, have already limited employer prerogatives to terminate employees. ${ }^{71}$

The common law rule of termination at will ${ }^{72}$ is indefensible even on pure efficiency grounds. It does not accurately reflect the bargain that most parties would have struck had they negotiated a complete employment contract. Due to the high transaction costs of bargaining for each employee's contract and the high costs to the employee of obtaining the information necessary to perceive the true value of protection, failure to negotiate these terms is to be expected. ${ }^{73}$ Because employees bear most risks of termination, employers have little incentive under the termination at will rule to avoid unjustified dismissals, including those that represent retaliation against employee speech. ${ }^{74}$

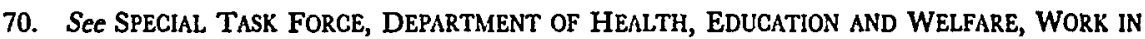
AMERICA 98-102 (1972) (summarizing findings of worker participation innovations); C. PATEMAN, supra note 53, at 90-91 (Yugoslavian system of worker participation not been hindrance to economic expansion; may have contributed, with other factors, to sizeable growth rate).

71. See A. ShONFIELD, MODERN CAPITALISM 113-114 (1965) (restrictions on European employer's freedom to dismiss); Summers, Individual Protection Against Unjust Dismissal: Time for a Statute, 62 VA. L. REV. 481, 508-19 (1976) (listing foreign provisions); see generally Kahn-Freund, Labor Law and Social Security, in 1 AMERICAN ENTERPRISE IN THE EUROPEAN COMMON MARKET: A LEGal PROFile (E. Stein \& T. Nicholson eds. 1960) (development in Europe). Japan has also adopted job security provisions. See Note, supra 17, at 1836 n.105 (citing Japanese law).

72. The carliest articulation of the termination at will rule appeared in an 1877 treatise on Master and Servant. Glendon \& Lev, supra note 39 at 458 . The rule assumes that employer and employee possess equal bargaining power in negotiating an employment contract and provides that, where no termination clause is explicitly agreed upon, the employment relationship can be ended at any time by either party. The rule enjoyed almost unanimous judicial popularity in the early part of the century. See Adair v. United States, 208 U.S. 161, 172-176 (1908) (mutuality of employment relationship). For histories of the rule, see Glendon \& Lev, supra note 39, at 457-61; Note, supra note 17 at 1824-28. For a history of the rule in Germany, France, England and Sweden, see Summers, supra note 71 , at $508-19$. The rule has been severely criticized by commentators. See note 1 , supra (Blades, Blumberg).

73. See Note, supra note 17, at 1830-33. Because "contract bargaining will yield optimal allocations of risks only when the costs of negotiating and of gathering information are negligible; . . . [these] barriers produce nonoptimal allocations (of risks)." Id. at $1830 \mathrm{n} .80$. In the context of collective bargaining, these terms actually are negotiated and usually result in "just cause" clauses or in mandatory arbitration clauses. See 2 Collective BARGaining NEGOTIATION \& CONTRACTS (BNA) 40:1 (1978) (90\% of contracts analyzed have some kind of grounds for discharge provision). Unions have not insisted, however, on explicit free speech protections. This is not unexpected, due to a kind of institutional failure. Established unions are as likely to perceive a threat from employee speech as are employers. See NLRB v. Magnavox, 415 U.S. 322, 325 (1974) (self-interest of incumbent union would operate to limit $\S 7$ rights); Holodnak v. Avco, 514 F.2d 285, 286-87 (2d Cir.), cert. denied, 423 U.S. 892 (1975) (inadequate union support at arbitration hearing for dismissal of employee who had been critical of union). See also Landrum-Griffin Act of 1959, 29 U.S.C. $\S 411$ (a)(2) (1976) (granting union members free speech rights within unions). Cf. 42 U.S.C. \& 2000e-2(c) (1976) (Title VII protects workers from discrimination by union as well as by employers). In only one context have union leaders endorsed an explicit collective bargaining clause protecting constitutional rights. See Lynd, Company Constitutionalism?, 87 YALE L.J. 885, 894 (1978) (book review) (citing newspaper report of campaign for presidency of United Steelworkers of America between incumbent Lloyd McBride and dissident Ed Sydlowski).

74. Note, supra note 17 , at 1834. 


\section{Employer's Freedom of Expression}

The First and Fourteenth Amendments also preserve the employer's rights of free expression from abridgment by government, even when the employer is an artificial person. ${ }^{75}$ Governmental protection of employee speech might violate these rights in two contexts: when the employee's speech is attributed to the employer, and when the employer exists merely as a proxy for the views and beliefs of its members.

First Amendment rights may be violated when a government forces a party to tolerate remarks which a reasonable listener would attribute to her. ${ }^{76}$ Such attribution, it is argued, compels the party to abandon her right of silence and forces her "to participate in the dissemination of an ideological message." ${ }^{\prime 77}$ When the employee can be perceived by the reasonable listener as a spokesperson for the employer, the listener might properly attribute the employee's speech to the employer, thus impairing the latter's rights of free expression.

Employers have the right to be free from unwanted attribution to them of ideological messages. Attribution by a reasonable listener depends, however, on the circumstances of the speech and the rank of the employee. High-ranking employees are likely to be identified as spokespersons, whether on or off the job. ${ }^{78}$ Lower-level employees who act as spokespersons on company time are also likely to be so identified. ${ }^{79}$ Therefore, these two types of employees should not ordinarily be protected by government from employer retaliation. Employees who do not fall into these categories, however, may be protected without infringing upon the employer's expressive rights.

The employer's First Amendment rights are also abridged where the

75. First Nat'l Bank of Boston v. Bellotti, 435 U.S. 765, 795 (1978) (corporations enjoy a degree of free specch); Clagett \& Bolton, Buckley v. Valeo, Its Aftermath and Its Prospects: The Constitutionality of Government Restraints on Political Campaign Financing, 29 VAND. L. REV. 1327, 1375 (1976) (after Buckley, no reason why corporations should not be as fully protected as unions and voluntary associations); Note, The Corporation and the Constitution: Economic Due Process and Corporate Speech, 90 YALE L.J. 1833 (1981) (urging that Bellotti be overturned).

76. Sec, e.g., Wooley v. Maynard, 430 U.S. 705, 713 (1977) (Jehovah's Witnesses may not be convicted for obscuring words "Live Free or Die" on state license plates); West Va. Bd. of Educ. v. Barnette, 319 U.S. 624 (1943) (government may not force schoolchildren to salute and pledge allegience to flag).

77. Pruneyard Shopping Center v. Robins, 447 U.S. 74, 85-87 (1980) (summarizing and affirming holding in Wooley).

78. This principle lies behind the denial of First Amendment protection to "policymaking" public employees. See Mitchell v. King, 537 F.2d 385, 391 (10th Cir. 1976) (governor properly discharged appointee who disagreed with policy goals); $c f$. Branti v. Finkel, 445 U.S. 507, 518-19 (1980) (policymaking distinguished from non-policymaking in context of patronage dismissals); Elrod v. Burns, 427 U.S. 347, 367-68 (1976) (plurality opinion) (same). There may, however, be circumstances where high-ranking employees are able to express themselves without identifying the employer. No danger would exist in these cases.

79. Thus, while a receptionist may not be fired for membership in the Klan, she may be fired for repeating Klan rhetoric to the firm's callers. 
employer itself is a representative organization. In a society increasingly dominated by large, intrusive institutions, individuals often find it necessary to band together to make their views known or to protect their individual liberties. The right of individuals to express themselves through amplifying organizations is well established.$^{80}$ Where the employer is an amplifying organization, its First Amendment rights are proxies for the expressive and associational rights of its members. ${ }^{81}$ Governmental regulation interfering with the primary protected purpose of an association substantially infringes the members' expressive and associational rights, because employee speech that diverges or distracts from the group's ideological message may strike at the heart of the group's protected purpose by impairing its ability to persuade.

Restraints on an amplifying association, however, will impermissably impair its members' associational rights only when such restraints substantially interfere with the amplifying association's primary protected purpose. The Supreme Court has found that regulation designed to eliminate racial discrimination, for example, violates no associational right when applied to a private school that exists to teach ideas or dogma, because the regulation in no way inhibits the group's primary purpose. ${ }^{82}$ If the state were to prohibit discrimination by the school on the basis of employee's ideas or dogma, however, the prohibition would interfere with the primary purpose of the amplifying group and thus constitute a substantial infringement of its members' associational rights.

Unlike political or ideological associations, an association that exists primarily for economic purposes will not suffer substantial impairment of its associational rights as a result of state protection of employee speech. ${ }^{83}$ Though such protection should not be extended to employees of political or ideological associations that exist primarily to amplify the view of their

80. See, e.g., NAACP v. Button, 371 U.S. 415,428 (1963); NAACP v. Alabama ex rel. Patterson, 357 U.S. 449, 458-60 (1958).

81. NAACP v. Alabama ex rel. Patterson, 357 U.S. 449, $459-61$ (1958), see Raggi, An Independent Right to Freedom of Association, 12 HARV. C.R.-C.L. L. REV. 1, 11-14 (1977) (arguing for independent right of freedom of association).

82. See Runyon v. McCrary, 427 U.S. 160, 175-76 (1976) (application of § 1981 to school that refused admission to black children found not to violate parents' freedom of association: parents have First Amendment right to send children to school that teaches desireability of racial segregation, but practice of excluding racial minorities from same institution is not protected by same principle); $\mathbf{L}$. TRIBE, supra note 42, at 704 (distinguishing between cases where association's protected purpose is threatened from those where it is not). But see Raggi, supra note 81, at 15-18, 25-26 (criticizing reasoning in Runyon, but not result). Cf. R. WOLFF, B. MOORE, JR., \& H. MARCUSE, A CRITIQUE OF PURE TOLERANCE 88-90, 93-95 (1969) (tolerance which treats dissent and status quo equally is repressive because status quo will prevail; dissenters will be left harmless and helpless to effect qualitative social change).

83. It is possible to distinguish between primarily economic and primarily ideological associations. See O'Kelley, The Constitutional Rights of Corporations Revisited: Social and Political Expression and the Corporation after First National Bank v. Bellotti, 67 GEO. L.J. 1347, 1359-66 (1979) (tracing "associational rationale" used to grant First Amendment rights to organizations). 
members and to persuade listeners, protection of employee speech in those economic associations whose central purpose is not to disseminate an ideological message will not interfere substantially with the associational rights of either the employer or its constituents. ${ }^{84}$

Even when employee speech is not attributable to the employer, and even when the employer is not an amplifying association, the employer may still have an interest in employee speech, particularly when it is directly or indirectly critical of the employer. Arguably, the employer should be able to demand and receive from every employee a minimum level of loyalty ${ }^{85}$-an intangible faithfulness to collective purposes above and beyond the contractual terms of the employment relationship. Loyalty to the employer's purpose and objectives may be a legitimate part of measuring job performance, ${ }^{86}$ especially in the case of high-ranking and policymaking employees whose duties often are less susceptible to description and measurement. ${ }^{87}$ Low- and middle-level employees, however, who usually have more specialized tasks and whose job performance is therefore more easily measurable, should not be required to display the same kind of loyalty. Indeed, restrictions placed on employee speech in an attempt to foster loyalty may have the opposite effect. To the extent that employees fear arbi-

84. Although an employee's criticism of a business employer might result in financial losses to the employer and thus be an interference with the purpose of the employer, this criticism would not interfere with the employer's primary protected purpose unless it violated property rights. See supra pp. 533-35.

85. Cf. RESTATEMENT (SECOND) OF AGENCY $\S 387$ (1958) (agent has duty to principal to act solely for principal's benefit in all matters connected with agency).

Loyalty may also function to stem frm decline. Firms experiencing decline in product quality are notified of the decline by a combination of "exit"-consumers stop buying the product-and "voice"-consumers complain about the dissatisfaction. Exit, however, is not sufficient to identify firm pathologies causing dissatisfaction; voice is also essential. Loyalty operates to deter exit from deteriorating firms and activates critical "voice" which aids management in reversing decline. Consumer loyalty thus operates to identify these pathologies to management. Excessive use of exit without voice leads to firm failure because management cannot respond quickly enough. Conversely, excessive use of voice without exit also fails to trigger necessary management response. This theory is more fully set out in A. HIRSCHMAN, EXIT, VOICE \& LOYALTY (1970).

Employees can also identify quality declines. Indeed, employees may possess information vital to recovery yet unavailable to management through ordinary hierarchical channels. See Boulding, The Economics of Knowledge and the Knowledge of Economics, 56 AMERICAN ECON. REV. 1, 8 (Supp. 1966) (organizational structure almost always produces false images to decision-maker). Employees are more likely than consumers to feel loyalty to the employer. Moreover, if the firm operates in an area where employees are scarce, the satisfaction of employees may be as important to the firm's health as the satisfaction of consumers. Employees are the "consumers" of workplaces, and thus are the only source of voice capable of stemming decline in the quality of the workplaces.

86. Where loyalty is not essential to measurement of performance, it should not be required. Some states have made it illegal to require employees either to purchase goods from a particular firm or to refrain from doing so. See, e.g., ARIZ. REV. STAT. ANN. $\$ 23-203$ (West 1971); CAL. LABOR CODE $\S$ 450 (West 1971); FLA. STAT. ANN. \& 448.03 (1977); LA. REV. STAT. ANN. \& 12:963 (West 1964).

87. As managerial discretion increases, the possibility of non-productive behavior also increases. However, as an employee's position rises in a hierarchy, it may become easier to measure performance in terms of division or group output for which that employee has responsibility. Thus, high level employees are not uniformly unmeasureable, and loyalty is therefore not uniformly necessary. 
trary retaliation for their ideas, they will believe themselves unfairly treated and thus become dissatisfied and disloyal. ${ }^{88}$ Criticism of the employer may represent loyalty to the employer's long-term interests; ${ }^{89}$ such long-term loyalty depends on freedom of expression.

\section{Employer's Freedom from Governmental Intrusion}

Employers may also have privacy rights that limit governmental protection of employee speech. Where the employer is a small family business, or resembles one in operation, such protection would intrude upon the constitutionally protected privacy of the individual, the home, and the family. ${ }^{90}$ Those employers that resemble the family should therefore be spared the intrusion that governmental protection of employee speech would require. As a business begins to acquire more characteristics of a corporate bureaucracy and fewer of a family enterprise, however, the employer's interest in privacy diminishes proportionally. ${ }^{91}$ Thus, by excluding small employers from employee speech regulations, government can protect employee speech without infringing upon an employer's constitutional privacy rights.

The existence of countervailing employer rights and interests does not diminish the importance of employee speech to the system of free expression. When employee speech can be protected without serious damage to other protected rights, it should be. Thus, employer interests are not a

88. See J. GALBRAITH, THE NEW INDUSTRIAL STATE 151-58 (2d rev. ed. 1971) (motivation of production, supervisory, clerical, sales workers is mixture of pecuniary and group identification incentives). An employer's ban on speech will preclude the employees' use of voice, or criticism, to promote recovery from decline. Thus, firm decline cannot be stemmed by employees. Moreover, leaving the firm, or exit, is made exceedingly difficult by social and economic pressures. See supra notes 39-40. Where both voice and exit are curbed, repression must occur. Hirschman, supra note 54 . Therefore, while internalized loyalty may operate to stem firm decline, externally-imposed loyalty is merely repression.

89. See A. Hirschman, supra note 85. Disloyalty to the employer also may result from a higher loyalty to the community or to the public. Comment B of $\S 387$ of the RESTATEMENT (SECOND) OF AGENCY (1958) provides:

The agent is also under a duty not to act or speak disloyally, except in the protection of his own interests or those of others. He is not, however, necessarily prevented from acting in good faith outside his employment in a manner which injuriously affects his principal's business.

(Emphases added.)

Indeed, federal law encourages such disloyalty in some contexts. Several federal statutes prohibit employer reprisal for disclosing violations of the statutes. See, e.g., Federal Mine Safety and Health Act of 1977, 30 U.S.C. $\$ 815$ (c)(1)-(3) (Supp. III 1979); Toxic Substances Control Act of 1976, 15 U.S.C. $\$ 2622(\mathrm{a})$-(e) (1976). For a list of some of the existing federal and state statutes, see WHISTLEBLOWING: LOYALTY AND DISSENT IN THE CORPORATION 173 (A. Westin ed. 1981).

90. T. EMERSON, supra note 2, at 682 . Modern Supreme Court decisions, see, e.g., Stanley v. Georgia, 394 U.S. 557, 564-565 (1969) (right of privacy in home); Griswold v. Connecticut, 381 U.S. 479, 482-84 (1965) (grounding federal right of privacy in First Amendment), have found a federal right of individual privacy protecting the home and family. See Reich, The New Property, 73 YALE L.J. 733, 785 (1964) (recognizing need for "zone of privacy for each individual beyond which neither government nor private power can push").

91. T. EMERSON, supra note 2 , at 682 . 
complete barrier to enhanced protection of expressive rights in the private sector; rather, they must be balanced against the need for such protection. ${ }^{92}$

\section{Standards and Institutions for Employee Speech Protection}

Policy concerns and countervailing constitutional rights do not by themselves create the specific legal rules necessary for effective protection of employee speech; nor do they suggest the governmental institutions most appropriate for such activity. Existing guarantees in state constitutions provide the best foundation for protection of private employee speech. In implementing these guarantees, state courts should employ a two-part inquiry, culminating in a balancing test, to determine the proper standard to apply.

\section{A. A Legal Basis for Protection of Employee Speech}

State constitutions were drafted not to limit federal power but to protect individual liberty. ${ }^{93}$ Indeed, thirty-nine state constitutions affirmatively protect freedom of speech in comprehensive terms that do not suggest mere limitations on governmental action. ${ }^{94}$ This breadth is not merely fortuitous; the principles of state action, growing primarily out of a concern for states' rights and federalism, are not applicable to enforcement of state

92. See T. EMERSON, supra note 2, at 8 (society may not promote other goals by suppressing beliefs or opinions of individual members); cf. NLRB v. Babcock \& Wilcox Co., 351 U.S. 105, 112 (1956) (accommodation between employees' $\$ 7$ rights and employer's property rights must be made "with as little destruction of one as is consistent with the maintainance of the other").

93. See, e.g., R. RANKIN, STATE CONSTITUTIONS: THE BILL OF RightS 4-5 (1960); Grad, The State Bill of Rights, in 7 CONSTITUTIONS OF THE UNITED STATES: NATIONAL AND STATE 117, 118 (1980). While the federal constitution grants power to the federal government, states possess all sovercign powers except as limited by the state constitutions. See Pruneyard Shopping Center v. Robins, 447 U.S. 74, 84 (1980) (states are "possessed of residual authority that enables [them] to define property in the first instance"); $c f$. THE FEDERALIST, No. 84 (A. Hamilton) (the people are sovereign; they retain all power not granted to state).

94. Most provisions take the form: "Every citizen may freely speak, write and publish his sentiments on all subjects, being responsible for the abuse of that right." N.Y. CONST., art. I $\$ 8$ (McKinney 1968). For a list of the 41 states conforming to this affirmative model, see Note, Private Abridgment of Speech and the State Constitutions, 90 YALE L.J. 165, $180 \mathrm{n.79}$ (1980). The language of the New York constitution resembles the comprehensive terms of the Thirteenth Amendment, which provides that "[n]either slavery nor involuntary servitude . . . shall exist within the United States, or any place subject to their jurisdiction." U.S. CONST. amend. 13, § 1. Although federal enforcement of other amendments has been limited by the application of the state action doctrine based on the terms of those amendments, federal enforcement of the Thirteenth amendment extends beyond non-governmental affairs. Yackle, The Burger Court, "State Action," and Congressional Enforcement of the Civil War Amendments, 27 ALA. L. REV. 479, 550-57 (1975).

One state appellate judge has recognized the potential of a state constitutional free expression clause to protect against wrongful discharge. See Rozier v. St. Mary's Hospital, 88 IIl. App. 3d 994, 1008, 411 N.E.2d 50 (1980) (dissenting opinion) (questioning whether case at bar makes out instance of retaliatory discharge on basis of controverted facts, but indicating belief in possibility). 
constitutions. ${ }^{95}$ Indeed, it has been argued elsewhere that federal withdrawal from the field of private abridgement is itself a strong reason for states to protect expressive activity. ${ }^{96}$ Several states have ignored the public-private dichotomy when applying their own constitutional provisions." Even those state constitutions that merely restrict legislative action in provisions similar to the First Amendment ${ }^{98}$ have not yet been interpreted extensively or limited explicitly to public actors. ${ }^{99}$ Affirmative constitutional limitations thus might be implied, as non-textual limitations have been in Delaware. ${ }^{100}$ The Supreme Court has made it clear that a state may protect free speech beyond the scope of the First Amendment, even beyond the scope of public actors. ${ }^{101}$

Gonstitutional protection of private employees' expressive rights is more appropriate than is common-law protection, which is overruled too easily by legislative fiat. ${ }^{102}$ Freedom of expression has always relied upon an independent judiciary with constitutional power to protect individual

95. See Yackle, supra note 94 , at $484-85$ (state action doctrine promotes states rights by drawing a line between affairs governed by states and those subject to federal intervention). Concern for states rights, often thought of as the excuse rather than the reason for opposition to federal anti-slavery statutes, are the explicit grounds on which the state action doctrine was founded. See The Civil Rights Cases, 109 U.S. 3, 10-13, 17-18 (1883).

96. Note, supra note 94 , at 177 . It might be argued that employees enjoying the protection of $\S 7$ could not benefit from state constitutional protections because claims of unfair labor practices are preempted by the NLRA. See San Diego Bldg. Trades Council v. Garmon, 359 U.S. 236 (1959). The Supreme Court has recently found, however, that a state-law claim that could not be presented to the NLRB is not preempted. Sears Roebuck \& Co. v. San Diego Carpenters, 436 U.S. 180 (1978) (claim of common law trespass). Because a claim based on a state constitution cannot be brought before the NLRB, the area is not preempted. A conflict would exist, however, in some cases. See Emporium Capwell Co. v. Western Addition Community Organization, 420 U.S. 50 (1975) (doctrine of exclusivity requires employees protesting employer's racial discrimination to first win union backing).

97. See Robins v. Pruneyard Shopping Center, 23 Cal. 3d 899, 153 Cal. Rptr. 854, 592 P.2d 341 (1979), aff', 447 U.S. 74 (1980) (no mention of state action doctrine when interpreting state free speech clause to protect against private abridgment of speech), cf. Sharrock v. Dell Buick-Cadillac, 45 N.Y.2d 152, 379 N.E.2d 1169 (1978) (ignoring state action doctrine when applying state due process requirements to private garage).

98. The states are Hawaii, Indiana, Oregon, South Carolina, Utah, West Virginia. See Note, supra note 94 , at 182 n.87.

99. Note, supra note 94 , at 178 . But see Note, supra note 94 , at $178 \mathrm{n} .64$ (some states have implicitly adopted federal doctrine of state action by interpreting their speech provisions in pari materia with First amendment).

100. Cf. State v. Ceci, 255 A.2d 700 (Del. Super. Ct. 1969) (implying free speech protection although only free press clause appears in state constitution).

101. Pruneyard Shopping Center v. Robins, 447 U.S. 74 (1980).

102. Further, common law reform along the lines of "wrongful discharge" doctrine merely provides a clause for contracts in which no term is negotiated. Employers need merely include a waiver of the clause in a standard contract to avoid common law liability. But see Note, supra note 17, at 1833 n.91 (arguing that courts might still refuse to enforce such clauses). Moreover, the common law may be particularly unsuited to protection of free speech, as speech cannot be valued in economic terms. Cf. Posner, The Economic Approach to Law, 53 TEX. L. REV. 757, 764 (1975) (logic of law is really economics; common law revolves around economic principles). But see Schwartz, Tort Law and the Economy in Nineteenth-Century America: A Reinterpretation, 90 YALE L.J. 1717, 1721, 1775 (1981) (empirical study shows tort law not singlemindedly geared to promoting economic efficiency). 
rights from majoritarian suppression, ${ }^{103}$ constitutional protection being most appropriate for those interests inadequately protected by majoritarian institutions. Because speech requiring protection usually is unpopular, it is not unexpected that democratically controlled legislatures fail to respond adequately. ${ }^{104}$

Total reliance on constitutional schemes, however, presents other difficulties. Constitutional doctrine can become prematurely inflexible unless significant case law has developed. ${ }^{105}$ Moreover, courts might not be properly equipped to analyze the economic interests involved in the balancing of employer and employee rights. ${ }^{106}$

But courts protecting private employees' speech under state constitutions need not proceed without any guidance. They may rely on analogous case law protecting public employees' speech and interpreting section 7 of the NLRA. ${ }^{107}$ They also may receive support from legislative action within appropriate spheres. The judiciary is capable of clearly separating the different variables that lead to the result in a given case, distinguishing those that the constitution requires from those that it does not. The legislature thus may be invited to establish presumptions for certain of these non-constitutional variables, the range of which, despite rudimentary constitutional limits, is still broad. For example, a legislature might establish presumptions concerning the definition either of "small business" with an eye to promoting employee harmony within constitutional limits, ${ }^{108}$ or of activities constituting "disruption of work." 109

103. See T. EMERSON, supra note 1, at 13; Note, supra note 94, at 178. See also Deutsch, Neutrality, Legitimacy and the Supreme Court: Some Intersections Between Law and Political Science, 20 STAN. L. REV. 169, 242 (1968) (reasons to favor courts over legislatures when deciding constitutional issues).

104. J. ELY, supra note 44; THE FederaLisT, supra note 43. Even Professor Wellington, who argues against constitutional remedies to limit non-governmental institutions, see note 1, supra, admits that "[c]onstitutional restraints could be effective limitations on union or corporate power in areas involving the treatment of employees and of those secking work in an enterprise." Wellington, supra note 1, at 348-49 (footnote omitted); cf. M. SHAPIRO, FREEDOM OF SPEECH: THE SUPREME COURT AND JUDICIAL REVIEW 2 (1966) ("in the free speech area, the Supreme Court (properly) represents some interests groups while other government agencies represent others."). Moreover, reliance on majoritarian institutions may be unwise in this instance. Competition among state legislatures for business development is not unknown in American history. See Liggett Co. v. Lee, 288 U.S. 517, 54864, 559 (1933) (Brandeis, J., dissenting) (describing changes in corporation law of various states: "The race was one not of diligence but of laxity.")

105. Cf. Deutsch, supra note 103 (fiexibility helps reduce conflict between judicial and public opinions, alleviating counter-majoritarian friction).

106. Cf. Andrus v. Allard, 444 U.S. 51, 66 (1979) ("Prediction of profitability is essentially a matter of reasoned speculation that courts are not especially competent to perform.")

107. One author has concluded that, due to the doctrinal borrowing between the protections accorded to the speech of public and organized private employees, the approaches of the two are now nearly indistinguishable. Lynd, supra note 8 , at 712,754 .

108. See note 128 infra (discussing presumptions based on size of employer).

109. Indeed, Iegislatures may wish to establish administrative agencies similar to the Equal Employment Opportunity Commission or the National Labor Relations Board. Although final determination of the constitutional issue may perhaps not be left with a non-judicial entity, $c f$. Alexander $v$. 


\section{B. Toward Determining the Limits of Employee Speech}

A two-step procedure highlights in broad strokes the issues that courts must address when deciding employee speech cases. The procedure first eliminates the enforcement of certain employee claims that would violate the employer's constitutional rights and then identifies the issues to be balanced in the remainder of the cases. ${ }^{110}$

\section{Threshold Issues}

A threshold test for enforcement of employee speech rights should eliminate those cases in which any enforcement would significantly impair the employer's federally protected interests. A threshold test is necessary to avoid state violation of federally guaranteed rights. The First Amendment right to freedom of association precludes protection of free speech when the employer exists primarily to amplify the views of its members or to protect their individual liberty. ${ }^{111}$ Respect for the integrity of our system of self-government and for the protection of freedom of expression itself requires that political associations remain largely unrestrained. These amplifying enterprises are characterized by an ideological viewpoint shared by all members; the enterprise engages primarily in expression and sees amplification of that ideological viewpoint as its most important purpose. ${ }^{112}$ Organizations like the Ku Klux Klan, the Moral Majority, the American Givil Liberties Union, the NAACP, political campaign committees, and the Republican and Communist parties all qualify as amplifying entities. Business corporations and labor unions, however, which are organized primarily to wield economic power, would not qualify. Newspapers that exist primarily to disseminate ideas but not ideology would likewise fail the test. Small employers should also be excluded from state constitutional proscriptions by virtue of the resemblance of their structure and operations to the truly private affairs of family and home. ${ }^{113}$

This threshold test would eliminate most violations of employers' con-

\footnotetext{
Gardner-Denver Co., 415 U.S. 36, 44-47 (1974) (unanimous) (finding arbitration an inappropriate forum for final determination of rights guaranteed by Title VII of the Civil Rights Act and requiring courts to determine question de novo), courts may find useful an administrative determination of a component matter such as the extent of employer loss. Indeed, those states that already have labor relations boards or employment discrimination commissions might wish to assign these determinations to those experienced bodies. Moreover, arbitration could also consider this constitutional issue. J. GETMAN, supra note 19, at 369-70; Palmer, supra note 19, at 170.

110. The proposed procedure relies heavily on public employee precedent. For doctrinal summaries, see R. O'NEIL, THE RIGHTS OF GOVERNMENT EMPLOYEES (1978); Lynd, supra note 8; Van Alstyne, The Constitutional Rights of Teachers and Professors, 1970 DUKE L.J. 841 (1970).

111. See supra pp. 538-39.

112. See O'Kelley, supra note 83.

113. See supra p. 540 . Legislative action would be particularly helpful in the context of defining "small business" beyond the constitutional privacy standard set by the courts.
} 
stitutional rights. Because the threshold test operates to deprive employees' speech of constitutional protections, the employer should have the burdens of proof and persuasion. Moreover, the kinds of information required by the test-description of the organization's size and purpose-are more easily obtained and presented by the employer. ${ }^{14}$

\section{Issues to Weigh in the Balance}

A balancing of additional interests is next required to ensure both minimal infringement upon relevant employer rights and maximum protection of employee speech rights. ${ }^{115}$ In performing this balancing, courts should consider the relation of the speech to the employee's job, its nature, and its disruptive effect on the employee's or employer's work.

\section{a. Relation of Speech to Job}

The balancing of employee speech rights against employer rights should also consider the relationship of the speech to the job performed by the employee speaker. The employer's interest in regulating employee speech should decrease as the speech becomes less related to the employee's job. Public employees enjoy protection that makes a similar calculation. ${ }^{116}$ Under this standard, for example, absent unusual circumstances, a switchboard operator's membership in the Ku Klux Klan, an assembly-line worker's affiliation with the Communist party, or a non-defense employee's degree of loyalty to the nation could not be a basis for employer retaliation.

114. Cr. Blades, supra note 1, at 1427-31 (discussing problems and burdens of proof in actions between employers and employees); Note, Free Speech and Impermissible Motive in the Dismissal of Public Employees, 89 YALE L.J. 376 (1979) (recommending change in standard of proof used in cases involving speech of public employees and recommending "substantial evidence" standard, primarily due to imbalance favoring employer in allocation of burden of proof).

115. See supra note 92.

116. See Pickering v. Board of Educ., 391 U.S. 563, $569-73$ (1968) (government, as employer, has no interest at all in speech that has little impact on speaker's job performance); $c f$. Pilkington v. Bevilacqua, 439 F. Supp. 465, 478 n.11 (D.R.I. 1977), affd per curium, 590 F.2d 386 (lst Cir. 1979) (public employee's right to First Amendment protection under Pickering justifiably based on rights qua employee as well as qua citizen); Blades, supra note 1, at 1406 (employer should not be allowed to exercise control over "innumerable facets of employee's life that have little or no relevance to the employment relationship"). Lower courts have required that reasons for dismissal of public employees be "narrowly related to the effective performance" of the employee's duties. See Sponick v. Detroit Police Dept., 49 Mich. App. 162, 211 N.W.2d 674 (1973). Thus, courts have overturned dismissals based upon employee advocacy of homosexuality, see Norton v. Macy, 417 F.2d 1161 (D.C. Cir. 1969), and have held that a police department may not refuse to hire an applicant because he legally practices nudism in his off-hours, see Bruns v. Pomerleau, 319 F. Supp. 58 (D. Md. 1970).

A court may also wish to consider the greater value of the speech to the public if the employee, due to her position within the entity, is the only source for the information or position espoused. Conversely, greater harm might be done to the entity if the position or information is faulty and the employer cannot easily correct the inaccuracy. See Pickering v. Board of Educ., 391 U.S. 563, 572 (1968). 
When an employee is reasonably percieved as a spokesperson for the employer, the employee's speech is too closely related to her job to be protected, for such protection would violate the employer's own First Amendment rights. ${ }^{17}$ Those high-ranking policymaking employees who ordinarily would be reasonably perceived as spokespersons, and official spokespersons should be required to serve at the pleasure of the employer. Exercise of professional judgment, however, should not operate to deny expressive rights unless the professional determines the policies of the enterprise. ${ }^{118}$

\section{b. Nature of the Speech}

Special value of the speech to the employee or to the public should weigh in favor of its protection, although such value admittedly will be subjective and difficult to gauge. Speech that has observable value to either the speaker or the public is worthy of protection, for it clearly promotes two of the underlying reasons for freedom of expression: self-realization for the speaker and informed decisionmaking by the electorate. ${ }^{119}$ Because of this standard's subjective nature, however, the absence of observable value to the public or to the speaker should not weigh against protection of the employee's speech. ${ }^{120}$

The fact that employee's statements are erroneous should weigh against their protection only when the statements are both unrelated to the job and knowingly and recklessly false. ${ }^{121}$ Protecting even false statements may promote the advancement of knowledge and the discovery of truth. ${ }^{122}$

117. See supra p. 537.

118. Cf. Branti v. Finkel, 445 U.S. 507, 519-20 (1980) (finding patronage dismissal improper where employee, a federal public defender, had significant powers of discretion but no responsibility for policies of agency).

119. See supra p. 529 (discussing values underlying freedom of expression).

120. Public employees are judged by a standard that includes consideration of the value of the speech. See Pickering v. Board of Educ., 391 U.S. 563, 571-72 (1968) (speech rights protect free and open decisionmaking vital to electorate). Pickering has occasionally been interpreted to limit speech protection to those issues important to the electorate-to issues concerning a matters of public concern. See Roseman v. Indiana Univ. of Pa., 520 F.2d 1364, 1367-69 (3d Cir. 1975), cert. denied, 424 U.S. 921 (1976) (non-tenured professor alleged that employer's failure to renew contract resulted from speech activity; court finds "reduced protection" for "private communications" of teacher). The Supreme Court, however, has found "private expression of one's views" deserving of protection as well. Givhan v. Western Line Consol. School Dist., 439 U.S. 410, 414, 415-16 (1979) (unanimous) (teacher's remarks to employer critical of school district, uttered in private encounters, found protected).

121. See New York Times Co. v. Sullivan, 376 U.S. 254, 279-80 (1964). The test has been used in formulating doctrines relating to both public and private employee speech. See Pickering v. Board of Educ., 391 U.S. 563, 573-74 (1968); Linn v. United Plant Guard Workers Local 114, 383 U.S. 53, 65 (1966) (Sullivan used not because of "constitutional compulsion" but only to give full effect to legislative intent of $\S 7$ of NLRA).

122. New York Times Co. v. Sullivan, 376 U.S. 254, 271-72 (1964) ("erroneous statement is inevitable in free debate, and ... must be protected if the freedoms of expression are to have the 
Therefore, the malicious intent test of New York Times Co. v. Sullivan ${ }^{123}$ should be employed in deciding employee speech cases. Only when speech is maliciously false should its falsity weigh against the employee's interest in free expression.

\section{c. Disruption of Work}

Courts further should consider whether employee speech results in tangible disruption of work. An employer must be able to require employees to obey instructions and to work effectively with their colleagues; ; $^{124}$ an employee's refusal to obey or inability to function as a part of a team can significantly impair the achievement of the employer's objectives. In order adequately to protect employer interests, therefore, the balancing must reflect an evaluation of whether the expressive activity disrupted work. ${ }^{125}$ Indeed, an employer's time, place and manner restrictions are reasonable only to the extent that they are necessary to minimize disruption. ${ }^{26}$

Nevertheless, the term "disruption" can describe almost any activity that the employer dislikes, and any expression is likely to be a minor disruption. Adequate protection of employee speech, therefore, requires that only material and substantial disruptions ${ }^{127}$ be heavily considered in the balance. ${ }^{128}$ Further, adequate protection of employer perogatives re-

'breathing space' that they 'need . . . to survive' ") (citing NAACP v. Button, 371 U.S. 415, 433 (1963)).

123. 376 U.S. 254,280 (1964).

124. See Pickering v. Board of Educ., 391 U.S. 563, 570 (1968) (recognizing need for obedience and "harmony among co-workers"); Blumberg, supra note 1, at 318 (obedience is "essential").

125. To the extent that employers have suffered losses amounting to a "taking," employee speech cannot be protected by government. The threshold test followed by consideration of "disruption" will ensure that no taking occurs. See supra pp. 533-37.

126. Cf. Republic Aviation Corp. v. NLRB, 324 U.S. 793, 803-04 (1945) (approving NLRB presumptions that time, place and manner restrictions are unreasonable unless shown to be "necessary in order to maintain production or discipline").

127. While Pickering suggested that insubordination and disharmony should be considered in the balance, most lower courts have replaced these factors with a test for material and substantial disruption, based on Tinker v. Des Moines Indep. Community School Dist., 393 U.S. 503, 513 (1969). See Lynd, supra note 8 , at 736 . Thus, activities involving only minor disruptions, such as making "illconsidered personal remark[s]" to a future superior, DeLuca v. Sullivan, 450 F. Supp. 736, 740 (D. Mass. 1977), filing a lawsuit to challenge the election of superiors, Gomez v. Board of Educ., 85 N.M. 708, 516 P.2d 679 (1973), or calmly but publicly criticizing superiors, Dendor v. Board of Fire \& Police Commissioners, 11 III. App. 3d 582, 297 N.E.2d 316 (1973), have all been protected when balanced against the employers' interests. Courts have also reversed dismissals based solely on the failure of co-workers to "weather minor upsets" provoked by the dismissed employee. See Commonwealth ex rel. Rafferty v. Philadelphia Psychiatric Center, 356 F. Supp. 500, 508-09 (E.D. Pa. 1973). Conversely, where speech has substantially and materially disrupted the work of the organization, it has often been unprotected. Thus, employees in psychotherapeutic wards at Veteran's Hospitals have been prohibited to wear small pins registering their opposition to war because this expression could impede the recovery of recent veterans, see Smith v. United States, 502 F.2d 512, 514 (5th Cir. 1974), and probation officers have been prohibited to display posters suggesting admiration for unapprehended but wanted criminals, see Phillips v. Adult Probation Dept., 491 F.2d 951 (9th Cir. 1974). These expressive activities would substantially disrupt the work of the organization.

128. Note that the concern for harmony among co-workers, as comprehended by the concept of 
quires that the speech must substantially be the cause of the retaliation. ${ }^{129}$ In the private sector, "substantial disruption" should include fighting at work, ${ }^{130}$ persistent interruption of co-workers causing them seriously to threaten to resign, ${ }^{131}$ and persistent direct refusal to obey reasonable orders. ${ }^{132}$ "Insubstantial disruption" should include calmly criticizing operations and procedures, ${ }^{133}$ advising an employee of her legal rights against the employer, ${ }^{134}$ implying that an employer is racially biased, ${ }^{135}$ or engaging in an "unprofessional outburst" in the office of a superior. ${ }^{136}$ To the extent that any lost value is great enough to amount to a taking, and to the extent that an employer can directly trace such lost value to particular instances of employee speech, the loss should be considered in the threshold. ${ }^{137}$ Substantial loss of value can also be considered a serious disruption of the employer's enterprise.

\section{Conclusion}

The speech of public employees currently is protected by the First and Fourteenth Amendments, and that of union members when furthering

disruption, may lend itself to certain presumptions based upon the size of the employer. As an $\mathrm{cm}$ ployer's size decreases, it becomes less possible to create segregated groups of like-minded employees. Ideological differences may engender tensions so destructive that teamwork becomes impossible. Further, the importance of teamwork to the firm's operations is likely to increase as the size of the firm decreases.

A presumption based upon the size of the employer would be a beneficial surrogate for the harmony concern. Such a presumption would have the great advantage of promoting certainty in an area where courts might be slow to develop a predictable standard. Moreover, employers would find the presumption easily translatable into guidelines for use in their self-policing efforts. Thus, burdensome quantities of litigation could be avoided. In this way, small firms that are not family-operated and therefore unprotected by the constitutional right to privacy might yet be protected by a presumption against enforcement of employee speech rights based upon a constitutional concern for worker harmony.

129. When fashioning standards for employee speech, courts must consider the burden of persuasion. Employers defending against employee charges of speech-provoked retaliation are likely to allege that the employee would have suffered the same fate regardless of the speech. A "but for" test, which requires the employee to show that the employer had no other reason besides speech-provoked retaliation, will unduly favor the employer. See Note, supra note 114, at 393 (defects of "but for" causation should lead courts to employ "substantial cause" test when deciding public employee speech cases). But cf. Mt. Healthy City School District Bd. of Educ. v. Doyle, 429 U.S. 274 (1977) (applying butfor test of causation).

130. See, e.g., Edwards v. Foucar, Ray \& Simon, Inc., 24 Empl. Prac. Dec. (CCH) I 31,208, at 17,360 (N.D. Cal. 1980) (fighting with superior); Sexton v. Sears Roebuck \& Co., 17 Empl. Prac. Dec. (CCH) If 8452, at 6349 (S.D. Tex. 1978) (fighting among salesmen on sales floor).

131. See Taylor v. Franklin Drapery, 441 F. Supp. 279, 295-97 (W.D. Mo. 1977).

132. Cf. Gonzalez v. Bolger, 22 Empl. Prac. Dec. (CCH) I 30,731 , at 14,769 (D.D.C. 1980) (postal employee).

133. See supra note 29.

134. See supra note 34 .

135. See supra note 36.

136. See Lewis v. Ford Motor Co., 17 Empl. Prac. Dec. (CCH) I 8453, at 6350 (E.D. Mich. 1978).

137. See supra pp. 533-36. 
concerted activity, by the NLRA. Although federal courts have refused to apply the First Amendment to private employment relationships, the broader guarantees of provisions in state constitutions are suited to supply such protection. By developing a test that balances the employee's interest in free expression against the protected interests of the employer, state courts can intervene to protect employee speech without violating the employer's rights. ${ }^{138}$

Such a balancing test is the most appropriate way both to consider the many factors involved in employee speech cases and to insure that resulting doctrines remain flexible until a significant body of case law has developed. Such flexibility could be detrimental to the system of free expression, however, if applied inconsistently by courts according to their subjective respect for the content of the expression. ${ }^{139}$ Indeed, unpopular speech is the type most in need of protection. The elements of the test must be applied, therefore, with full cognizance of both the underlying purposes of free expression and the difficulties of ferreting out abuses of the system of free expression within the employment relationship. ${ }^{140}$

138. Remedies in such cases need not be limited to reinstatement. See Sherman, Reinstatement as a Remedy for Unfair Dismissal in Common Market Countries, 29 AM. J. COMP. L. 467, 506-507 (1981) (majority of all common market nations recognize appropriateness of reinstatement as a potential remedy but also have laws providing for monetary compensation). Reinstatement, however, is occasionally a worthwhile remedy. See McDermott \& Newhams, Discharge-Reinstatement: What Happens Thereafter, 24 IND. \& LAB. REL. REV. 526 (1971) (empirical study showing employer and employee satisfaction following reinstatement; few employees discharged second time); Glendon \& Lev, supra note 39 , at 462 (increased popularity of reinstatement as arbitration award). See generally Harrison, Wrongful Discharge: Toward a More Efficient Remedy, 56 IND. L.J. 207 (1981).

139. See T. EMERSON, TOINARD A GENERAL THEORY OF THE FIRST AMENDMENT, supra note 42 , at 53-56 (criticizing balancing test for vagueness); L. TRIBE, supra note 42, at 583-84 (same). But see Emerson, First Amendment Doctrine and the Burger Court, supra note 42, at 438 (most commentators accept balancing, though often as a last resort). Balancing is made less distasteful by limiting the terms that may be weighed. See Nimmer, The Right to Speak from Times to Time: First Amendment Theory Applied to Libel and Misapplied to Privacy, 56 CALIF. L. REV. 935, 935-48 (1968) (endorsing limited balancing test over "ad hoc" balancing test).

140. The low public visibility of the private employment relationship requires such examination. Cf. T. EMERSON, supra note 2, at 163 (low visibility of administrative decisions make "the imagined impact of the restrictions . . . the most repressive feature of all"). 